\title{
NATURAL BASIS FOR FAST-COOKED KISSEL
}

\author{
O. Lysyi, O. Hrabovska
}

National University of Food Technologies

\begin{tabular}{|c|c|}
\hline Key words: & ABSTRACT \\
\hline $\begin{array}{l}\text { Food concentrate } \\
\text { Kissel } \\
\text { Modified starch } \\
\text { Fruit powder } \\
\text { Rheology } \\
\end{array}$ & \multirow{3}{*}{$\begin{array}{l}\text { The article presents the results of studies of formulations of } \\
\text { instant cooking food concentrates of kissel enriched with } \\
\text { biologically active substances. A natural basis for kissel was } \\
\text { developed with the use of modified starch and fruit and } \\
\text { vegetable powders. Based on the conducted rheological stu- } \\
\text { dies and a comprehensive organoleptic quality assessment, it } \\
\text { has been found that the developed instant food kissel samples } \\
\text { have better structural, mechanical and organoleptic cha- } \\
\text { racteristics compared to commercially available samples of } \\
\text { kissel. The production of fast-cooking kissel on a natural basis } \\
\text { will expand the range of products for health improvement. }\end{array}$} \\
\hline $\begin{array}{l}\quad \text { Article history: } \\
\text { Received 04.05.2017 } \\
\text { Received in revised form } \\
28.05 .2017 \\
\text { Accepted } 14.06 .2017\end{array}$ & \\
\hline $\begin{array}{l}\text { Corresponding author: } \\
\text { O. Lysyi } \\
\text { E-mail: } \\
\text { npnuht@ukr.net }\end{array}$ & \\
\hline
\end{tabular}

DOI: $10.24263 / 2225-2924-2017-23-4-28$

\section{НАТУРАЛЬНА ОСНОВА ДЛЯ КИСЕЛЮ ШВИДКОГО ПРИГОТУВАННЯ}

\section{О.В. Лисий, О.В. Грабовська \\ Національний університет харчових технологій}

У статті наведено результати досліджень рецептур харчоконцентратів киселів швидкого приготування, збагачених біологічно активними речовинами. Розроблено натуральну основу для киселю з використанням модифікованих видів крохмалю та фруктових і овочевих порошків. На основі реологічних досліджень $і$ проведеної комплексної органолептичної оцінки якості встановлено, щзо розроблені зразки киселю швидкого приготування мають кращі структурно-механічні і органолептичні характеристики порівняно $з$ наявними у торговельній мережі видами киселів. Виробництво запропонованого киселю швидкого приготування на натуральній основі розширить асортимент продуктів оздоровчо-профілактичного призначення.

Ключові слова: харчоконцентрат, кисіль, модифікований крохмаль, фруктові порочки, реологія.

Постановка проблеми. На сьогодні на ринку України представлено широкий асортимент продукції харчоконцентратного виробництва, в тому числі і харчових концентратів десертних страв. До більшої частини даної 
групи продукції за оригінальними рецептурами включені фруктові або плодово-ягідні наповнювачі, проте згідно з чинними нормативними документами дозволено замінювати натуральні, природні наповнювачі та добавки синтетичними (барвники, ароматизатори, смакові добавки тощо). Цим часто користуються виробники харчоконцентратної продукції з метою зменшення собівартості продукції та нарощування обсягу виробництва за рахунок заміни натуральних складових. Це призводить до значного зменшення харчової цінності кінцевого продукту, а також ставить під сумніви можливість його використання у харчовому раціоні дітей і людей похилого віку [2; 5].

Слід відмітити, що харчові концентрати (ХК), у складі яких використано натуральні компоненти, також мають певні недоліки. Так, наприклад, сухі плодово-ягідні киселі, до складу яких входять плодово-ягідні екстракти, одержані шляхом уварювання прозорих соків, мають ряд недоліків. Відсутність в екстрактах пектинових речовин зменшує їх харчову цінність. Тривалість технологічного процесу одержання екстрактів призводить до руйнування вітамінів і втрати інших біологічно активних речовин. Екстракти, які використовують для приготування харчоконцентратів киселів, мають відносно низький вміст сухих речовин (СР). Так, масова частка СР в екстракті 3 винограду становить $62 \%$, журавлини - $54 \%$, чорної смородини - $44 \%$. Масова частка СР ХК киселю ( $\approx 94 \%)$ не завжди досягається купажуванням, тому суміш часто доводиться підсушувати, додатково втрачаючи при цьому корисні речовини і енергію. Крім того, при змішуванні екстрактів з цукром у процесі виробництва сухих киселів утворюється липка маса, яка перешкоджає механізації процесу фасування готових продуктів. Такий кисіль необхідно заварювати окропом, доводити до кипіння і варити протягом $3-5$ хв, що, у свою чергу, вимагає додаткових енерговитрат та часу [5].

Термічна обробка суміші (використання окропу) негативно впливає на термолабільні біологічно активні речовини (БАР), а саме6 вітаміни тощо, та призводить до їх часткового або повного руйнування, тому вміст БАР в готовому продукті буде низький.

Мета статті: розроблення рецептур і дослідження якісних показників киселів швидкого приготування на основі модифікованих видів крохмалю, збагачених фруктовими порошками.

Викладення основних результатів дослідження. Для визначення оптимальної кількості компонентів при складанні рецептур концентратів киселів було застосовано математичне моделювання процесу приготування киселю, в основі якого симплекс-метод. Реологічні характеристики готових зразків киселю досліджено за допомогою роторного віскозиметра «Реотест-2». Органолептична оцінка якості розроблених зразків киселю була визначена методом побудови багатокутника.

Розробка рецептури харчоконцентрату киселю на основі набухаючого крохмалю (НК), збагаченого фруктовими порошками

Для вирішення завдання запропоновано використати як структуроутворювач крохмаль модифікований набухаючий, а як наповнювач - натуральний високодисперсний фруктовий порошок. Крім того, до складу рецептури даного киселю швидкого приготування входить цукор, лимонна та аскорбінова кислоти. 
Внесення набухаючого крохмалю в рецептуру кисілю має важливе значення для швидкості та якості приготування готової страви. Особливістю даного виду крохмалю $є$ підвищена здатність набухати та частково розчинятися у холодній воді, утворюючи однорідний клейстер. Такий ефект досягається при вологотермічному та вологотермомеханічному обробленні суспензії нативного крохмалю. Основна перевага використання модифікованого набухаючого крохмалю полягає в тому, що в процесі приготування киселю не потрібно проводити термічне оброблення або використовувати окріп, достатньо додати теплу або воду кімнатної температури. При цьому утворюється драглеподібна структура ніжної текстури, що має кращі органолептичні показники (кремоподібна консистенція, відсутність присмаку та запаху крохмалю) порівняно із показниками клейстеру, отриманого нагріванням нативного крохмалю.

Додавання модифікованого НК до складу сухої суміші киселю у кількості $20 \ldots .23 \%$ дає змогу отримати продукт 3 оптимальною консистенцією (помірна плинність, кремоподібна текстура).

Введення до складу киселю фруктових порошків підвищує харчову та енергетичну цінність продукту. Фруктові порошки містять значну кількість вуглеводів, мінеральних речовин, вітамінів і флавоноїдів, збагачують кисіль швидкого приготування пектиновими речовинами, поліфенольними речовинами та каротиноїдами. За рахунок додавання органічних кислот (винної, яблучної, лимонної) покращуються смакові якості продукту.

Рівень вмісту фруктових порошків знаходиться в межах $11 \ldots 16 \%$, що забезпечує оптимальні органолептичні показники продукту. Як основний наповнювач використовується порошок з яблучної сировини.

Аскорбінова кислота $є$ природним антиоксидантом, що захищає від впливу кисню інші речовини харчових продуктів, які можуть окиснюватися (напр. фруктові і овочеві порошки), відповідно подовжуючи термін зберігання продукту. Також вона перешкоджає небажаним змінам кольору продукту, пов'язаним 3 ферментативними процесами. Вітамін С має також важливе фізіологічне значення для організму людини оскільки бере участь в обмінних процесах, стимулює процеси синтезу преколагену і перетворення його в колаген. Завдяки цьому підтримується нормальна проникність капілярів, збереження цілісності опорних тканин (фіброзної, хрящової, кісткової). Також вітамін С стимулює захисні сили організму, покращує засвоєння заліза 3 їжі, впливає на білковий обмін, сприяє утворенню кортикостероїдів, покращує регенеративні процеси.

Введення до рецептурної суміші киселю аскорбінової кислоти в межах $0,15 \ldots 0,25 \%$ задовольняє добову потребу організму людини у вітаміні $\mathrm{C}$ на $60 \ldots 100 \%$, а також забезпечує подовжений термін зберігання продукту завдяки антиоксидантним властивостям.

Лимонна кислота використовується як синтетичний антиоксидант, регулятор кислотності та стабілізатор забарвлення. Лимонна кислота широко застосовується у напоях і десертах з метою надання їм приємного кислого смаку і нотки свіжості.

При помірному вживанні лимонна кислота стимулює діяльність підшлункової залози, збуджує апетит, сприяє засвоєнню їжі. Вона є синергістом, 
тобто речовиною, що підсилює дію антиоксидантів, таких як аскорбінова кислота.

Вміст лимонної кислоти у рецептурній суміші киселю у кількості $1,5 \ldots 1,8 \%$ дає змогу регулювати кислотність залежно від виду фруктових i/aбо овочевих порошків, щоб забезпечити помірний кислий смак продукту.

Враховуючи результати попередніх досліджень і оптимізації компонентів рецептурної суміші, розроблено рецептуру киселю швидкого приготування на натуральній основі «Фрутик», яка наведена у табл. 1.

Таблиия 1. Рецептура киселю швидкого приготування «Фрутик»

\begin{tabular}{|c|c|}
\hline Назва сировини & Вміст, $\%$ \\
\hline Крохмаль модифікований набухаючий & $20,0-23,0$ \\
\hline Порошок фруктовий і/або овочевий & $11,0-16,0$ \\
\hline Кислота лимонна & $1,5-1,8$ \\
\hline Кислота аскорбінова & $0,15-0,25$ \\
\hline Цукрова пудра & решта \\
\hline
\end{tabular}

Виробництво запропонованого киселю швидкого приготування на натуральній основі розширить асортимент продуктів оздоровчо-профілактичного призначення.

Зручність і швидкість у приготуванні дає змогу застосовувати кисіль натуральний швидкого приготування у будь-яких умовах: експедиціях, відрядженнях, лікарнях, заощаджувати час, енергоресурси та витрати праці.

Розробка рецептури харчокониентрату киселю на основі монокрохмалефосфату, збагаченого фруктовими порошками

Кисіль на основі нативного крохмалю має короткий термін зберігання після його приготування, оскільки 3 часом крохмальні драглі, внаслідок ретроградації, виявляють схильність до синерезису та відшарування рідкої фази, що погіршує його органолептичні показники. Наявність цукру і кислоти посилює синерезис при зберіганні, тому завдання полягало в тому, щоб створити кисіль швидкого приготування 3 підвищеним вмістом БАР і подовженим терміном зберігання в готовому вигляді.

Для цього у складі киселю швидкого приготування як структуроутворювач і наповнювач було використано модифікований фосфатний крохмаль, а як наповнювач - високодисперсний фруктовий i/або овочевий порошок, цукор і лимонну кислоту при співвідношенні компонентів, які наведені в табл. 2.

\section{Таблиия 2. Рецептура киселю швидкого приготування «Фруктовий рай»}

\begin{tabular}{|c|c|}
\hline Назва сировини & Вміст, \% \\
\hline Крохмаль фосфатний & $15,0-20,0$ \\
\hline Порошок фруктовий i/або овочевий & $18,0-24,0$ \\
\hline Кислота лимонна & $1,4-1,6$ \\
\hline Цукор білий кристалічний & решта \\
\hline
\end{tabular}

Внесення фосфатного крохмалю в рецептуру киселю має важливе значення для забезпечення однорідної консистенції напою та збереження іiі 
протягом тривалого часу. Особливістю фосфатного крохмалю порівняно 3 нативним $є$ те, що він утворює при нагріванні більш прозорий, густий i в'язкий клейстер, стійкий до ретроградації при тривалому вистоюванні. Перевага цього крохмалю в тому, що його клейстери стійкі до зміни температури та $\mathrm{pH}$ середовища, крім того, для приготування готової страви на його основі достатньо додати гарячу воду. При цьому утворюється однорідна, легкоплинна, прозора структура ніжної консистенції, без присмаку та запаху сирого крохмалю. Приготовлений кисіль на основі фосфатного крохмалю стійкий до розшарування та зміни консистенції протягом 48 годин.

Додавання модифікованого монокрохмальфосфату до складу сухої суміші киселю в межах 15..20\% дає змогу отримати продукт 3 ніжною консистенцією (помірна текучість, кремоподібна текстура).

Введення до складу киселю фруктових високодисперсних порошків, завдяки їх швидкій відновлюваності при додаванні води, дає змогу отримати стійку пюреподібну структуру 3 відмінними органолептичними властивостями. Також при внесенні порошків збільшується харчова й енергетична цінність продукту. Фруктові та овочеві порошки збагачують кисіль швидкого приготування пектином, поліфенольними речовинами та каротиноїдами. За рахунок органічних кислот (винної, яблучної, лимонної) покращуються смакові якості продукту. При розробленні рецептури киселю було використано порошок яблука. Як природні барвники можливе використання порошків моркви або столового буряка, а як смакові i ароматичні добавки порошки цитрусових. Рівень вмісту порошків у рецептурі киселю в межах $18 \ldots 24 \%$ забезпечує оптимальні органолептичні показники продукту.

Використання запропонованого киселю швидкого приготування дає можливість не лише розширити асортимент продуктів харчування, а й використовувати його як продукт підвищеної біологічної цінності.

Дослідили реологічні характеристики киселів швидкого приготування, збагачених біологічно активними речовинами, і порівняли зі зразком киселю відомої торгової марки (ТМ) «Мрія», до складу якого входить цукор, крохмаль картопляний нативний, лимонна та аскорбінова кислоти, барвники, ароматизатори.

Як відомо з попередніх досліджень [3], на набухання крохмалю і, відповідно, утворення структури, тією чи іншою мірою впливають різні речовини залежно від їх концентрації. Тому з метою визначення структурно-механічних характеристик структур киселів проведено дослідження зразків на віскозиметрі типу «Реотест-2». Для дослідження було обрано три зразки киселю, два 3 яких розроблено нами: № 2 «Фрутик», № 3 «Фруктовий рай», а зразок № 1 кисіль ТМ «Мрія» використано як контрольний. Приготування і дослідження всіх зразків відбувалося в однакових умовах: кожен зразок був залитий гарячою водою (окропом) при перемішуванні для розчинення усіх компонентів, охолоджений до кімнатної температури $\left(20^{\circ} \mathrm{C}\right)$. Співвідношення сухого киселю і води обрано згідно з рекомендаціями для приготування. Для вимірювання на віскозиметрі з кожного приготовленого дослідного зразка було відібрано порцію об'ємом $100 \mathrm{~cm}^{3}$.

На основі результатів обробки даних, знятих з віскозиметра «Реотест-2», було побудовано повні реологічні криві в’язкості та плинності. Для деталь- 
ного аналізу реологічних властивостей досліджуваних зразків було розраховано комплекс реологічних параметрів. Для вивчення впливу внесених інгредієнтів на властивості киселю при розчиненні у воді було обрано реологічні параметри $P_{m}, P_{r}$ i $\left(\eta_{0}-\eta_{m}\right)$ [4].

Показник $\left(\eta_{0}-\eta_{m}\right)$ (Па·c) характеризує міцність коагуляційних структур, що утворюються в системі; $P_{m}($ Па) - відповідає напрузі практично зруйнованої структури, а $P_{r}($ Па) - напрузі практично не зруйнованої структури, два останніх показники характеризують міцність утвореного структурного каркасу.

На діаграмі (рис. 1) представлено значення аномалії в'язкості $\left(\eta_{0}-\eta_{m}\right)$ досліджуваних зразків киселю.

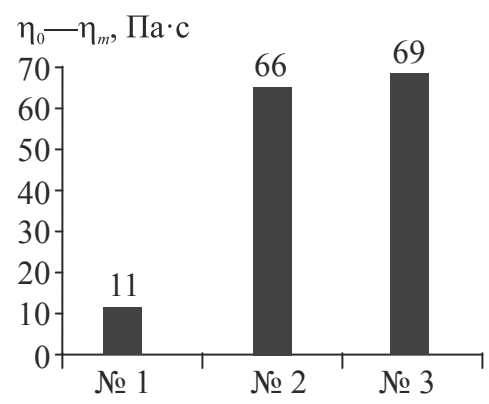

Рис. 1. Величина аномалії в'язкості досліджуваних зразків киселю $\left(\eta_{0}-\eta_{m}\right)$, Па·с: № 1 ТМ «Мрія» (контроль), № 2 «Фрутик», № 3 «Фруктовий рай»

3 діаграми видно, що найміцнішу структуру, а отже, і найбільшу в'язкість, мають зразки № 2 і № 3. Обидва ці зразки містять цукор, фруктовий порошок і лимонну кислоту в приблизно однаковому співвідношенні. Відмінність полягає лише у використаному структуроутворювачі: зразок № 2 містить набухаючий картопляний крохмаль, а № 3 - кукурудзяний монокрохмальфосфат. Порівняно з контролем показник аномалії в'язкості для зразків № 2 i № 3 більший у 6 разів.

На рис. 2 наведено значення напруги практично зруйнованої і незруйнованої структури досліджуваних зразків киселю.

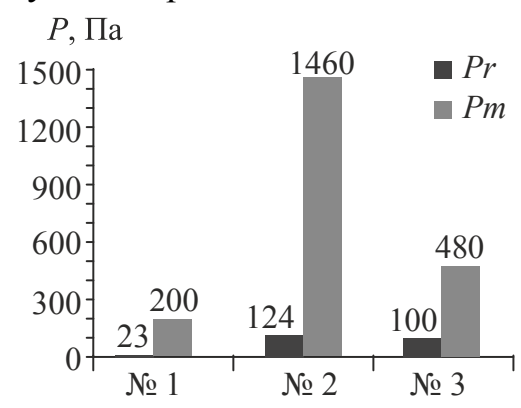

Рис. 2. Напруга практично зруйнованої структури $\boldsymbol{P}_{m}$, i напруга практично не зруйнованої структури $\boldsymbol{P}_{r}$ досліджуваних зразків киселю, Па: № 1 ТМ «Мрія» (контроль), № 2 «Фрутик», № 3 «Фруктовий рай»

Найкращі результати відповідають більшим значенням показників напруги, за яких структура залишається практично не зруйнованою, притаманні 
зразкам № 2 і № 3 (рис. 2), які в 5 і 4 рази відповідно перевищують значення контрольного. А значення напруги для практично зруйнованої структури $\left(P_{m}\right)$ дають іншу картину. Найбільше значення цього показника у зразка № 2 , яке в 7 разів перевищує значення контрольного і майже втричі - значення зразка № 3. Це пояснюється тим, що за однакових умов кукурудзяний монокрохмальфосфат не утворює міцного структурного каркасу.

При досліджені реологічних параметрів розроблених зразків киселю швидкого приготування, виявилося, що всі зразки мають кращі реологічні показники порівняно 3 контрольним. Це пов'язано 3 використанням у складі рецептур киселів модифікованих видів крохмалю, а також підбором і співвідношенням інших компонентів. Аналізуючи результати реологічних досліджень, а також органолептичної оцінки, за консистенцією контрольний зразок (№ 1) можна віднести до рідкого (питний), а зразки № 2 і 3 - до середньо густих.

Органолептична оиінка якості киселів.

Органолептична оцінка якості розроблених зразків киселю проводилася за методом побудови багатокутника якості. Відповідно до даного методу за кольором, смаком, запахом, консистенцією та зовнішнім виглядом визначали ступінь проявлення кожної з цих властивостей за десятибальною шкалою. Це дало можливість визначити вплив компонентів на якість виробу і порівняти розроблені рецептури з уже існуючими зразками киселю.

Відповідний бал кожного показника є середнім арифметичним, наданим усіма членами дегустаційної групи. Для визначення загальної оцінки кожного зразка за отриманими балами було побудовано багатокутники. Загальна оцінка якості зразку відповідає площі багатокутника.

На рис. 3 представлено профілограми органолептичної оцінки якості досліджуваних зразків киселів. Зразок а (ТМ «Мрія», полуничний смак) придбаний у торговельній мережі як контроль. Зразок б - кисіль швидкого приготування на основі цукру та фруктових порошків, як структуроутворювач використаний НК. Зразок в містить у своєму складі цукор, фруктовий порошок і монокрохмальфосфат.

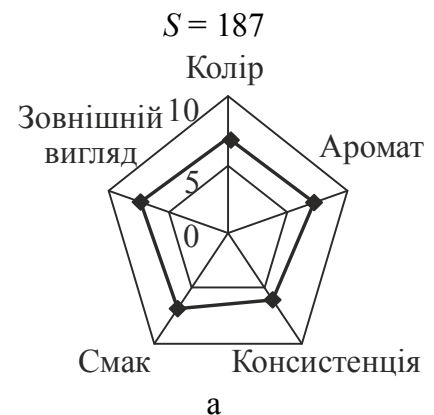

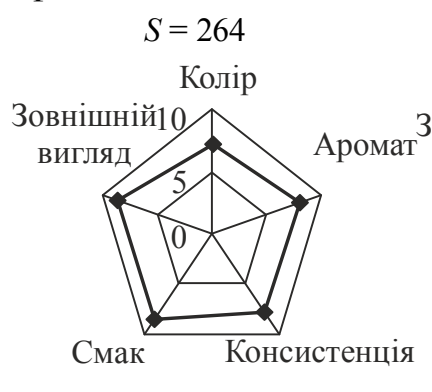

б

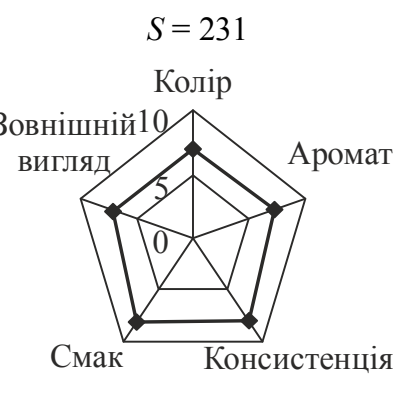

B

Рис. 3. Профілограми органолептичної оцінки якості зразків киселю: $\mathrm{a}$ - ТМ «Мрія» (контроль); б — «Фрутик»; в — «Фруктовий рай»

Найвищу оцінку отримав зразок б (рис. 3) - 264 бали, оскільки має високі оцінки за усіма показниками. Зразок киселю в набрав 231 бал, через нижчі оцінки кольору і зовнішнього вигляду, що пов'язано з використанням кукуру- 
дзяного монокрохмалефосфату, який не дає гарної прозорості. Контрольний зразок а - ТМ «Мрія» - набрав лише 187 балів через рідку консистенцію, неприродно яскравий колір та надмірно виражений аромат і солодкість.

Органолептична оцінка якості вказує на те, що досліджувані зразки киселю на натуральній основі мають чудові органолептичні характеристики i можуть конкурувати 3 наявними у торговельній мережі видами киселів.

\section{Висновок}

На підставі проведених досліджень розроблено рецептури киселів швидкого приготування «Фрутик» i «Фруктовий рай», збагачених біологічно активними речовинами. На основі реологічних досліджень і комплексної органолептичної оцінки якості встановлено, що розроблені зразки киселю швидкого приготування мають кращі структурно-механічні і органолептичні характеристики порівняно з наявними у торговельній мережі видами киселів. Зручність і швидкість приготування дає змогу застосовувати харчоконцентрати киселю, збагачені біологічно активними речовинами, у будь-яких умовах: експедиціях, відрядженнях, закладах харчування, заощаджувати час, енергоресурси та витрати праці.

\section{Лiтература}

1. Оттавей Б.П. Обогащение пищевых продуктов и биологически активные добавки / Б.П. Оттавей ; пер. 3 англ. - Москва : «Профессия», 2009. - 312 с.

2. Пищевые ингредиенты в создании современных продуктов питания : монография / под редакцией: Тутельян В.А., Нечаев А.П. — Москва : ДеЛи плюс, 2013. — 520 с.

3. Лисий О.В. Вплив харчових інгредієнтів на реологічні властивості набухаючого крохмалю / О.В. Лисий, О.В. Грабовська // Цукор України. - 2015. - № 3(111). — С. 33-38.

4. Дослідження структурно-механічних властивостей модельних систем на основі пектину / О.В. Грабовська, О.В. Запотоцька, О.В. Лисий, В.Я. Пічкур // Продовольча індустрія АПК. - 2012. - № 2. - С. 16-18.

5. Рудавська Г.Б. Харчові концентрати: підруч. / Г.Б. Рудавська, Є.В. Тищенко. Київ : Київ. нац. торг.-екон. ун-т, 2001. - 320 с.

6. Сарафанова Л.А. Пищевые добавки: энциклопедия / Л.А. Сарафанова. — 2-е изд., испр. и доп. - Санкт-Петербург : ГИОРД, 2004. — 808 с. 